\title{
Actual and Relative Soil Air Permeability as Soil Physical Quality Index
}

\author{
Ian Carlos Bispo de Carvalho ${ }^{2}$, Alexsandro dos Santos Brito ${ }^{1}$, Kaique Oliveira Matos ${ }^{1}$ \\ \& Marcelo Couto de Jesus ${ }^{2}$ \\ ${ }^{1}$ Federal Institute of Education, Science and Technology (IFBAIANO), Guanambi, Bahia, Brazil \\ Correspondence: Alexsandro dos Santos Brito, Federal Institute of Education, Science and Technology \\ (IFBAIANO), Guanambi, Bahia, Brazil. Tel: 55-773-493-2100. E-mail: alexsandro.brito@ifbaiano.edu.br
}

Received: April 7, $2019 \quad$ Accepted: June 4, $2019 \quad$ Online Published: August 31, 2019
doi:10.5539/jas.v11n14p1
URL: https://doi.org/10.5539/jas.v11n14p1

The research is financed by National Council for Scientific and Technological Development of Brazil (CNPq) and Federal Institute of Education, Science and Technology (IFBAIANO).

\begin{abstract}
Developing indices to evaluate soil physical quality can facilitate diagnosis and decision-making. In this context, intrinsic soil air permeability $\left(\mathrm{K}_{\text {air }}\right)$ is a physical parameter very sensitive to structural changes due to soil management. However, it is important to establish a standard $\mathrm{K}_{\text {air }}$, considering a reference soil physical state. Thus, the present study proposes to create an index called relative soil air permeability $\left(\mathrm{K}_{\text {airr }}\right)$, taking as reference the physical state of maximum bulk density, obtained by normal Proctor test. $K_{\text {airr }}$ is the ratio between compacted soil air permeability $\left(\mathrm{K}_{\text {airc }}\right)$ and actual soil air permeability $\left(\mathrm{K}_{\text {air }}\right) . \mathrm{K}_{\text {airr }}$ was evaluated using disturbed and undisturbed samples of a Latossolo and a Planossolo. The experimental design was completely randomized, with four treatments ( $\mathrm{T}_{1}$-Latossolo 0-0.1 m; $\mathrm{T}_{2}$-Latossolo 0.1-0.2 m; $\mathrm{T}_{3}$-Planossolo 0-0.1 m and $\mathrm{T}_{4}$-Planossolo 0.1-0.2 $\mathrm{m})$ and eight replicates. $\mathrm{K}_{\text {airr }}$ was equal to 0.1032 and 0.3547 in the Latossolo and to 0.4115 and 0.1923 in the Planossolo, in the 0-0.1 and 0.1-0.2 m layers, respectively. These characteristic values observed in both soils and layers are due to the management adopted in the area. In Latossolo, the use of medium harrow has made the 0.1-0.2 m layer more restrictive to air movement, whereas the Planossolo showed lower values of relative soil air permeability in the $0-0.1 \mathrm{~m}$ layer due to animal grazing, which has greater impact on the superficial portion of the soil.
\end{abstract}

Keywords: aeration, degradation, structure

\section{Introduction}

Anthropic actions in agricultural production systems can cause alterations in soil physical characteristics, which may vary in magnitude depending on the adopted management, causing positive or negative effects on the agroecosystem in which the activity is being conducted. Nevertheless, most agricultural activities developed by mankind have high potential for degradation of soil structure, which in the long term may cause deleterious effect on the maintenance of its productive viability.

Aiming at safe management of natural resources, quantitative analyses and interpretation of physical and physical-hydraulic attributes, which in turn allow measuring the main changes caused in soil quality, are fundamental (Stefanoski, Santos, Marchão, Petter, \& Pacheco, 2013). In this perspective, the importance of quantifying soil air permeability $\left(\mathrm{K}_{\mathrm{air}}\right)$ is due to the need for characterizing the porous space and identifying changes in soil structure, caused by management practices (Blackwell et al., 1990; Cavalieri et al., 2009; Schjonning \& Koppelgaard, 2017).

Soil air permeability is a parameter that allows establishing correlations with other soil attributes which are difficult to determine, such as hydraulic conductivity (Loll, Moldrup, Schjonning, \& Riley, 1999; Rahmati \& Neyshaboury, 2016), which indicates its versatility in terms of capacity to provide information on soil structural state, so as to allow reviewing actions, evaluating management strategies and correcting possible mistakes during the production process. Additionally, it allows obtaining data for environmental studies on the extraction of 
vapor of contaminants present in porous media of this nature (Fahran, Holsen, \& Budiman, 2001; Shi, Wu, Ai, \& Zhang, 2018).

Pore-size distribution, tortuosity and connectivity are the characteristics of the porous space geometry that most influence the transport of fluids in soil (Iversen, Moldrup, Schjønning, \& Loll, 2001; Tuli, Hopmans, Rolston, \& Moldrup, 2005; Chief, Ferré, \& Nijssen, 2006), whereas viscosity is the relevant attribute which characterizes the studied fluid (Libardi, 2012). Thus, soils with high $\mathrm{K}_{\text {air }}$ have greater capacity to exchange gases with the atmosphere, i.e., they have better aeration (Menezes et al., 2018). This is important because higher relative concentration of $\mathrm{CO}_{2}$ in soil, to the detriment of $\mathrm{O}_{2}$, due to metabolic activities of roots and soil biota, may compromise the yields of agricultural crops, when air renewal in soil is limited.

Soil structural degradation, in general, reduces water and air flows so that agricultural crops are not able to express their genetic potential. In this context, intrinsic permeability is the inherent soil attribute (Libardi, 2012) which translates the capacity to transport air through the interconnected air-filled pores (Chief et al., 2006). However, in Brazil, there is scarce information on $\mathrm{K}_{\text {air }}$, particularly for methodological reasons, associated with both measurement methods and equipment availability (Silva, Leão, Tormena, \& Gonçalves, 2009; Rodrigues, Silva, Giarola, \& Rosa, 2011; Silveira, Brito, Mota, Moraes, \& Libardi, 2011; Guedes Filho, Silva, Giarola, \& Tormena, 2015; Jesus, Brito, Silva, Teixeira, \& Carvalho, 2017).

Different indicators of soil physical quality have been used to measure management effects on soil structural aspects (Klein, Baseggion, \& Madalosso, 2009; Loss, Pereira, Giacomo, Perin, \& Anjos, 2011; Moreira et al., 2014; Martínez et al., 2016; Brown, Barbosa, Bertoll, Mafral, \& Muzekal, 2018). Nonetheless, a common characteristic among these indicators is that, in general, they are direct or indirect expressions of pore volume and/or function of soil porous space (Reynolds, Drury, Tan, Fox, \& Yang, 2009).

Some indices have been created to establish correlations with other soil attributes, such as the index based on the ratio between soil air conductivity and aeration porosity, determined with samples equilibrated at $5.0 \mathrm{kPa}$ tension (Groenevelt, Kay, \& Grant, 1984), the index of structural organization, which is similar to the one previously mentioned, but uses soil air permeability instead of soil air conductivity (Blackwell et al., 1990) and the pore continuity index, which relates $\mathrm{K}_{\text {air }}$ with aeration porosity, using the Kozeny-Carman model (Ahuja, Naney, Green, \& Nielsen, 1984).

The existing soil physical quality indicators are generated for specific situations, requiring higher number of studies for validation and reliable application, which constitutes an opportunity to develop new soil physical quality indicators (Stefanoski et al., 2013). Thus, creating an index which allows more efficient distinction of soil physical quality is fundamental for decision-making regarding soil management.

The present study aimed to develop a soil physical quality index, which is based on intrinsic soil air permeability at two physical states, in order to allow a more efficient distinction of soil physical quality. This index has been called relative soil air permeability.

\section{Methods}

\subsection{Location of Soils}

The Latossolo and Planossolo evaluated are located in the experimental area of the Federal Institute of Education, Science and Technology (IFBAIANO), Guanambi Campus (geographic coordinates: $14^{\circ} 13^{\prime} 30^{\prime \prime}$ S, $42^{\circ} 46^{\prime} 53^{\prime \prime} \mathrm{W}$ and altitude of $525 \mathrm{~m}$ ), which is used for cultivation of vegetables, annual crops, fruit crops and grasses, besides scientific experiments. Soil samples were collected in the areas with agricultural systems, in order to assess their structural physical quality and validate the proposed index.

\subsection{Soil Air Permeability}

Air movement in soil was assessed according to the methodology developed by Kirkham (1946), using undisturbed soil sample to measure the intrinsic soil air permeability, which will be referred to herein only as soil air permeability (Silveira et al., 2011).

Air pressure in the cylinder at the beginning of each measurement was equilibrated at $1 \mathrm{kPa}(1 \mathrm{kPa}$ above local atmospheric pressure), causing air flow to be laminar and not lead to significant modifications in the water films on the surface of soil aggregates.

The $\mathrm{K}_{\text {air }}$ determination model, through the decreasing pressure method, was based on the Darcy's model, which requires laminar flow regime and, in the case of gas flow, an isothermal process. Thus, the reduction of internal pressure (manometric pressure) in the air cylinder was given by the following Equation (1): 


$$
\ln \mathrm{P}_{\mathrm{a} 1}-\ln \mathrm{P}_{\mathrm{a} 2}=\frac{\mathrm{K}_{\mathrm{air}} \mathrm{AP}_{\mathrm{atm}}}{\operatorname{LnV}}\left(\mathrm{t}_{2}-\mathrm{t}_{1}\right)
$$

where $\mathrm{P}_{\mathrm{a} 1}$ and $\mathrm{P}_{\mathrm{a} 2}$ are the manometric pressures (above atmospheric pressure) at times $\mathrm{t}_{1}$ and $\mathrm{t}_{2}$, respectively; $\mathrm{K}_{\mathrm{air}}$ is soil air permeability; $\mathrm{A}$ is the cross-section area of the undisturbed soil sample; $\mathrm{P}_{\mathrm{atm}}$ is the local atmospheric pressure; $\mathrm{L}$ is soil sample height; $\mathrm{n}$ is air viscosity; and $\mathrm{V}$ is the air cylinder volume.

By referring to $\mathrm{K}_{\mathrm{air}} \mathrm{APatm} / \mathrm{LnV}$ as $\mathrm{S}$ and knowing that this term represents the angular coefficient of the linear regression of pressure (Ln pressure) as a function of time, Equation (1) can be rewritten as:

$$
\ln \mathrm{P}_{\mathrm{a} 2}=-\mathrm{St}+\ln \mathrm{P}_{\mathrm{a} 1}
$$

Hence, the permeability $\left(\mathrm{K}_{\text {air }}\right)$ can be calculated from the regression $\operatorname{Ln} P_{a} x t$, which allows obtaining the angular coefficient $(S)$, and from it the soil air permeability:

$$
\mathrm{K}_{\mathrm{air}}=\left(\frac{\mathrm{LnV}}{\mathrm{AP}_{\mathrm{atm}}}\right) \times \mathrm{S}
$$

Soil air permeability was measured in undisturbed soil samples collected in the $0-0.1 \mathrm{~m}$ and $0.1-0.2 \mathrm{~m}$ layers, for both soils evaluated, in eight replicates. These samples were collected (soil pits) using Uhland-type sampler and volumetric cylinder with the following dimensions: $0.047 \mathrm{~m}$ diameter and $0.05 \mathrm{~m}$ height. For transportation to the laboratory, these undisturbed samples were wrapped in non-porous plastic film and placed in plastic box, covered on the inside with bubble wrap to avoid alterations during the transportation.

In the laboratory, the samples were properly prepared by removing excess soil, to make soil volume equal to cylinder volume, and placing the bottom part of the volumetric cylinder on a piece of blotting paper with the same diameter, to avoid soil losses and improve the contact between the sample and the porous surface of the tension table, during the process of stabilization at the tensions. After preparation, the samples were saturated using a container of greater height than the cylinders, gradually filled with deionized water up to $3 / 4$ of cylinder height, in order to expel all the air from soil pores. The samples were left under the saturation process for $24 \mathrm{~h}$.

The samples were equilibrated at $6.0 \mathrm{kPa}$ tension on a tension table. As soil air permeability is hampered by excess water or by degraded or even massive soil structure, which may result from a process of compaction, the choice of each tension becomes more important for the evaluation of this soil attribute. After equilibrium, the samples were weighed on precision scale, the blotting paper was removed with a stiletto, and the side of the soil sample in contact with the porous surface was slightly scarified.

The sample was then attached to the permeameter to determine soil air permeability. The permeameter consists of three parts: 1) injection compartment; 2) pressurized air cylinder ( $0.031 \mathrm{~m}^{3}$ volume) and 3$)$ data acquisition and processing system. The acquisition system is composed of an electronic module and the computer program PermeAR 1.0. The electronic module of the acquisition system consists of a differential pressure transducer (MPXV5004DP model, Freescale) with operating range from 0 to $3.92 \mathrm{kPa}$, sensitivity of $1.0 \mathrm{mV} \mathrm{Pa}^{-1}$ and accuracy of $\pm 1.5 \%$ of its full scale voltage. All sensors were connected to a microcomputer by a microcontroller (Basic Step M8 model, Tato ind.), which has a 10-bit (eight channels) internal A/D converter and internal voltage reference (Silveira et al., 2011).

\subsection{Relative Soil Air Permeability}

Relative soil air permeability $\left(\mathrm{K}_{\text {airr }}\right)$ was measured in soil samples in the worst physical condition. Disturbed soil samples were collected in the same layers where air permeability was determined and sieved through 4-mm-mesh sieve for the Proctor normal test (Klein, Madalosso, \& Baseggio, 2013), which aimed to produce soil samples at maximum compaction.

In samples with maximum bulk density (sample compacted in normal Proctor cylinder), subsamples were collected with the aid of a hydraulic press, using volumetric cylinders with the same dimensions as those used to measure soil air permeability.

The saturation process of these samples ended when a film of water was observed on the surface. After that, the samples were equilibrated in Haines funnels (6 kPa tension) and used in the determination of soil air permeability. After equilibrium, the samples were weighed and attached to the permeameter, where compacted soil air permeability $\left(\mathrm{K}_{\text {airc }}\right)$ was determined.

With the values of soil air permeability for both physical condition (actual and compacted soil), the relative soil air permeability was calculated according to Equation (4):

$$
\mathrm{K}_{\mathrm{airr}}=\frac{\mathrm{K}_{\text {airc }}}{\mathrm{K}_{\mathrm{air}}}
$$


Regarding the interpretation of results, after calculating the relationship between compacted soil air permeability $\left(\mathrm{K}_{\text {airc }}\right)$ and actual soil air permeability $\left(\mathrm{K}_{\text {air }}\right)$, the relative soil air permeability is calculated $\left(\mathrm{K}_{\text {airr }}\right)$ : if the value is close to one, the soil is degraded; if $\mathrm{K}_{\text {airr }}$ is closer to zero, the soil is in good physical quality.

\subsection{Particle size, Bulk Density and Pore-Size Distribution of the Soils}

Particle-size analysis was carried out by the pipette method (Gee \& Or, 2002) in the layers of 0-0.1 m and 0.1-0.2 m. However, a few variations recommended by the Soil Physics Laboratory of the IFBAIANO/Guanambi Campus were adopted in the procedure, such as the use of a dispersant composed of sodium hydroxide $\left(4 \mathrm{~g} \mathrm{~L}^{-1}\right)$ and sodium hexametaphosphate $\left(10 \mathrm{~g} \mathrm{~L}^{-1}\right)$ solutions, according to the methodology of IAC (Camargo, Moniz, Jorge, \& Valadares, 1986).

Bulk density was determined by the volumetric cylinder method. Soil samples used for permeability determination were also used for bulk density determination. For that, the heights and diameters of all rings were previously measured, in three replicates, using a digital caliper. The masses of the piece of blotting paper and volumetric cylinder were also estimated, in order to be subtracted during the soil sample mass calculation.

For soil dry mass determination, the samples were placed in the oven $\left(105{ }^{\circ} \mathrm{C}\right.$, for $\left.24 \mathrm{~h}\right)$ and weighed on precision scale. Bulk density was then calculated based on the mean volume of the volumetric cylinder, obtained from its mean height and diameter, and mass of dry soil.

\subsection{Data Analysis}

The experimental design was completely randomized, with four treatments $\left(\mathrm{T}_{1}\right.$-Latossolo Vermelho Amarelo in the 0-0.1 m layer; $\mathrm{T}_{2}$-Latossolo Vermelho Amarelo in the 0.1-0.2 m layer; $\mathrm{T}_{3}$-Planossolo in the 0-0.1 m layer; $\mathrm{T}_{4}$-Planossolo in the 0.1-0.2 m layer) and eight replicates, totaling 32 undisturbed soil samples. Four soil samples, with mass around $20 \mathrm{~kg}$, were also collected to construct compaction curves and particle-size graphs.

The data were initially subjected to exploratory analysis in R environment (R development core team, 2018), through the package Mass (Brian et al., 2018). Then, analysis of variance was carried out and means were compared by Tukey and Duncan tests, at $5 \%$ probability level, through the package ExpDes.pt (Ferreira, Cavalcanti \& Nogueira, 2018).

\section{Results and Discussion}

In the compaction curves for the two soils analyzed in the 0-0.1 $\mathrm{m}$ layer (Figure 1), maximum density was equal to $1,955 \mathrm{~kg} \mathrm{~m}^{-3}$ in the Latossolo (Figure 1A), whereas a lower maximum density $\left(1,845 \mathrm{~kg} \mathrm{~m}^{-3}\right)$ was found in the Planossolo (Figure 1B). This is due to the pedogenetic phenomenon of clay illuviation, which leads to higher presence of clay in the subsurface layers of the Planossolo (Oliveira, Ribeiro, Ferraz, Ferreira, \& Mermut, 2004), and this can be noted in the higher clay content in the $0-0.2 \mathrm{~m}$ layer, about $18 \%$ (Figure 2), especially in the B horizon, originated from the surface layer. Similar results were observed in a Planossolo located in the semi-arid region of Bahia, where particle-size analyses showed high sand contents in the entire profile, with increase in clay content in subsurface (Santos, Santos, Souza, Bahia, \& Rodrigues, 2013).
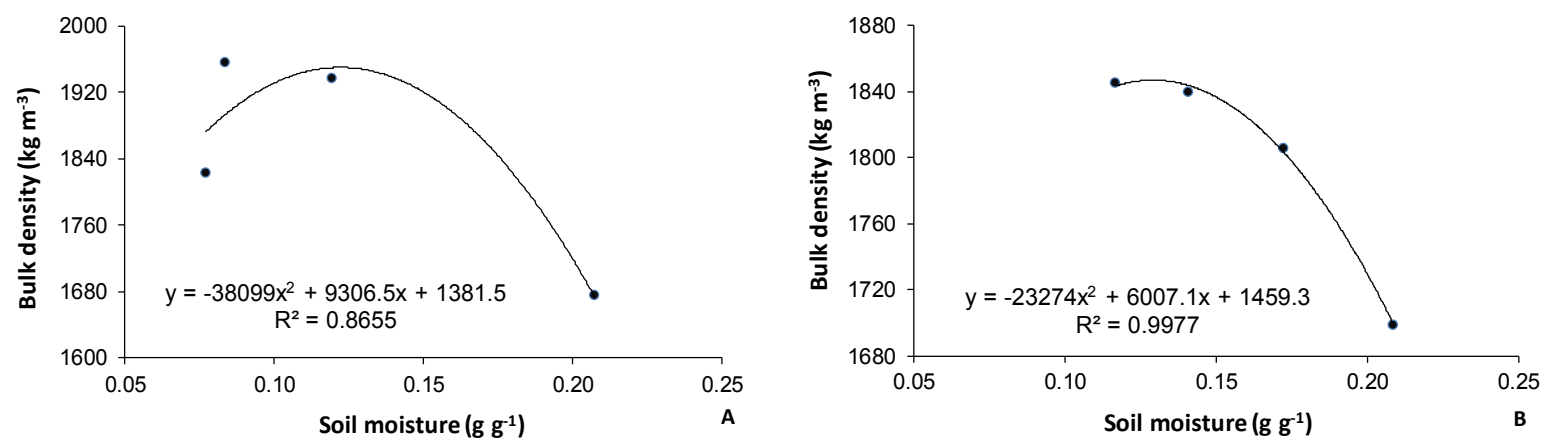

Figure 1. Compaction curves of the Latossolo Vermelho Amarelo (A) and Planossolo (B) in the 0-0.1 m layer 

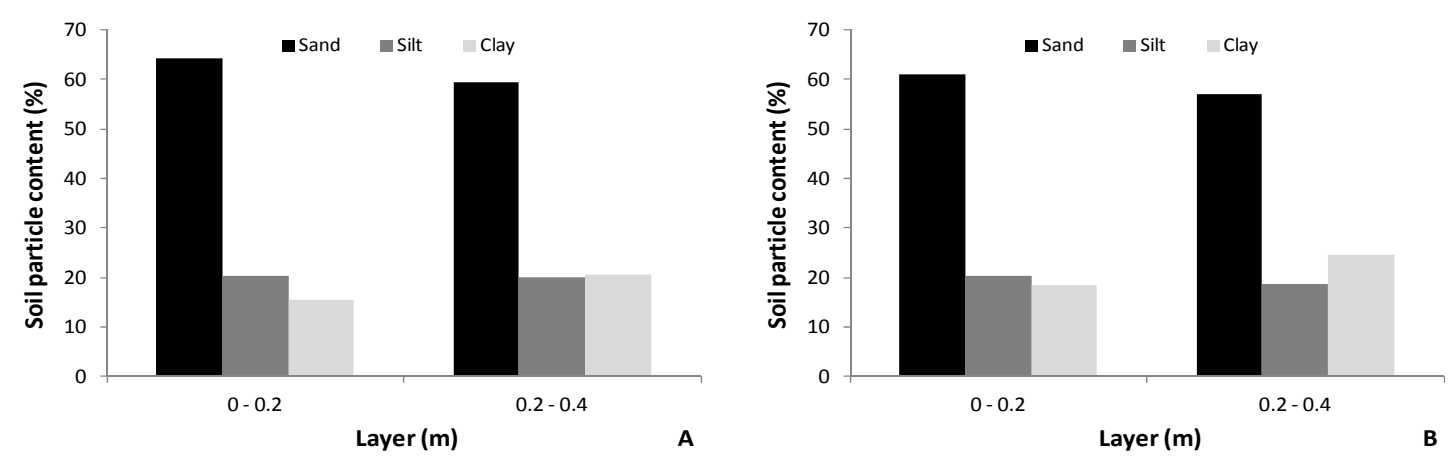

Figure 2. Percentages of sand, silt and clay in the Latossolo Vermelho Amarelo (A) and Planossolo (B)

The differences between the compaction curves of the two soils analyzed demonstrate that each type of soil has a maximum bulk density and a specific optimal moisture of compaction. Using these values for other soil classes may lead to errors in the determination of ideal moisture for management or evaluation of the current compaction state of an area. However, studying different types of soil allows obtaining reference values (Luciano, Albuquerque, Costa, Batistella, \& Armling, 2012).

There was an accentuated reduction of macroporosity in the 0.1-0.2 $\mathrm{m}$ layer of the Latossolo (Figure 3A), which differed statistically from the other layers analyzed. This considerably affects bulk density when the soil is compacted, due to a more cohesive arrangement, caused by the presence of an intermediate silt content and increase in clay concentration, which may become a limiting factor for crop development.
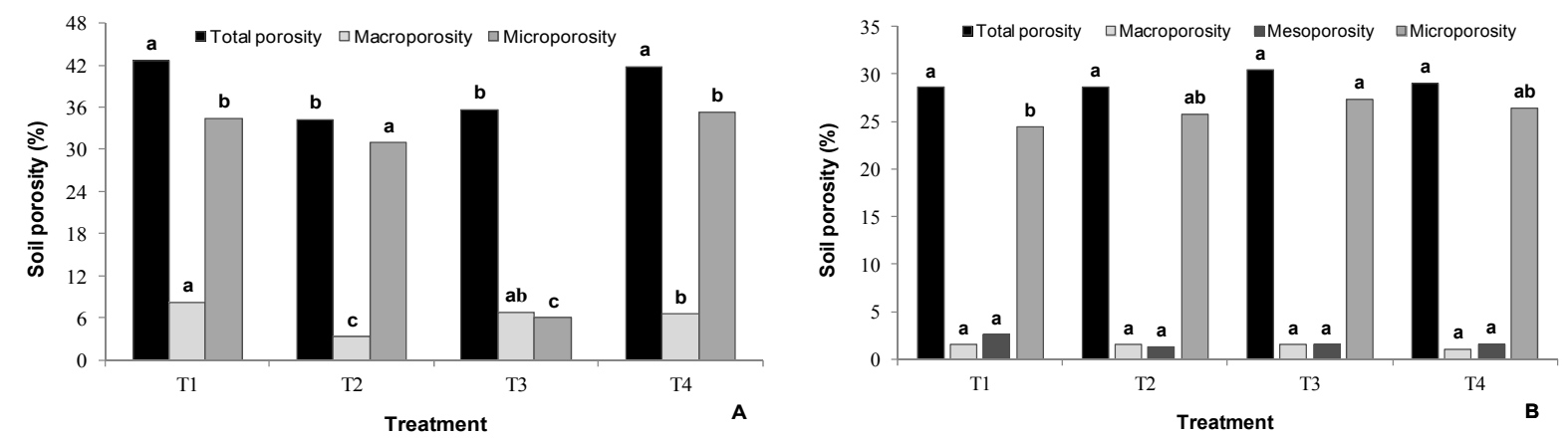

Figure 3. Porosity of the Latossolo in the layers of 0-0.1 m (T1) and 0.1-0.2 $\mathrm{m}$ (T2) and Planossolo in the layers of 0-0.1 m (T3) and 0.1-0.2 m (T4) in their natural state (A) and in the worst state of compaction (B). Means were compared by Tukey test at $5 \%$ probability level

The pressure exerted by the normal Proctor test drastically affects the porous space geometry (Figure 3B), modifying pore-size distribution. Macropores and mesopores were the ones which decreased the most, whereas micropores increased considerably, causing restrictions to air flow.

Reduction in aeration porosity, combined with other parameters, has direct impact on soil air permeability, causing its reduction (Tang, Cui, Richard, \& Défossez, 2011). Thus, the Planossolo in the 0-0.1 m layer showed the highest quantity of micropores, differing only from the Latossolo in the 0-0.1 m layer, which can be explained by the low clay content in this layer, since soil texture has influence on porosity (Dexter, 2004). In relation to total porosity, there was no statistical difference for any of the layers in the soils evaluated, as also observed for macroporosity and mesoporosity.

Therefore, when the soil is subjected to a pressure there is a change in the state of its pores, and macroporosity is the first parameter to undergo alterations, decreasing linearly as the pressure increases (Stone, Guimarães, \& Moreira, 2002; Silva, Albuquerque, \& Costa, 2014).

The percentage of micropores was statistically equal in both layers of the Latossolo, due to its uniformity, and of the Planossolo, despite the small increment in micropore percentage in the $0.1-0.2 \mathrm{~m}$ layer, compared to $0-0.1 \mathrm{~m}$ (Figure 3B). 
Regarding the bulk density of the soils in their natural state, the 0.1-0.2 m layer of the Latossolo had the highest value (Figure 4). This is particularly due to the soil management adopted in the area, where medium harrow has been used at the same depth, which allowed the formation of "harrow pan". Such increase of density due to management is directly linked to the reduction of macroporosity in subsurface layers (Viana, Batista, Tormena, Costa, \& Inoue, 2011), which corroborates the fact that the reduction in macroporosity is inversely proportional to the increase in soil density.

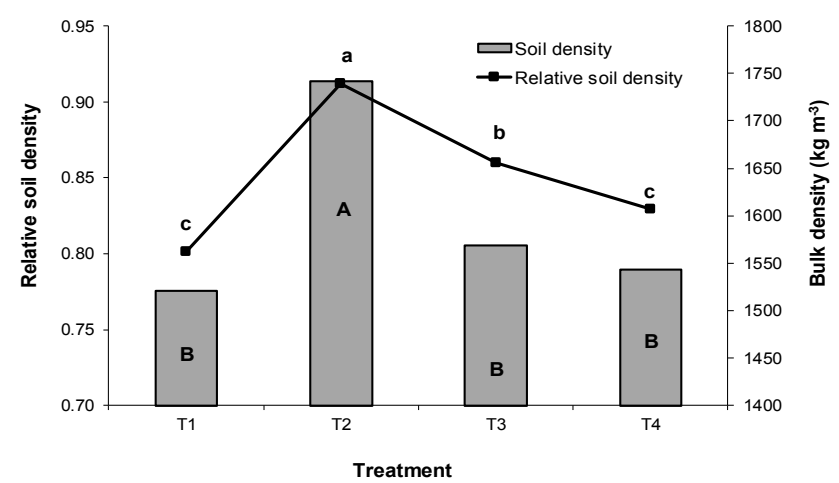

Figure 4. Relative soil density and bulk density in the natural state of the Latossolo in the layers of 0-0.1 m (T1) and 0.1-0.2 m (T2) and of the Planossolo in the layers of 0-0.1 m (T3) and 0.1-0.2 m (T4). Means were compared by Tukey test at $5 \%$ probability level

The relative soil density (Figure 4), for being a ratio between soil density in the worst state of compaction and soil density in the natural state, clearly reflects the variations of soil density in the natural state (Marcolin $\&$ Klein, 2011). It can be noted that soil density in the natural state, when high, may limit root development and the more degraded the soil structure, the more the relative soil density will approach the value 1, which reflects the worst density possible. Thus, it can be noted that the Latossolo in the 0.1-0.2 m layer, due to the high density caused by soil tillage management, had also a high relative density, above 0.9 , statistically differing from the other layers, hence reflecting a critical state of its structure.

The increase in soil density to high levels may lead to reduction in crop development and yield due to the restriction to root system growth. In a study with jatropha, its shoots were limited from the density of $1,260 \mathrm{~kg}$ $\mathrm{m}^{-3}$ in a clay-textured Latossolo, with reduction in the number of leaves, leaf area and shoot dry matter production (Ohland et al., 2014).

The relative density, therefore, serves as a parameter to assist in the decision-making regarding the intervention on soil physical structure. For that, measures of control of soil physical quality must be taken considering the warning values of soil density and critical soil density, based on either least limiting water range (Guimarães, Tormena, Blainski, \& Fidalski, 2013) or air permeability (Jesus et al., 2017).

Although the Latossolo in the 0-0.1 m layer was statistically equal to the Planossolo in the 0-0.1 m and 0.1-0.2 $\mathrm{m}$ layers with respect to density, their values of permeability differed, both in the natural state. In the Latossolo, the use of medium harrow improved soil density in the surface layer, but compacted the 0.1-0.2 $\mathrm{m}$ layer and this influenced air permeability (Figure 5). 


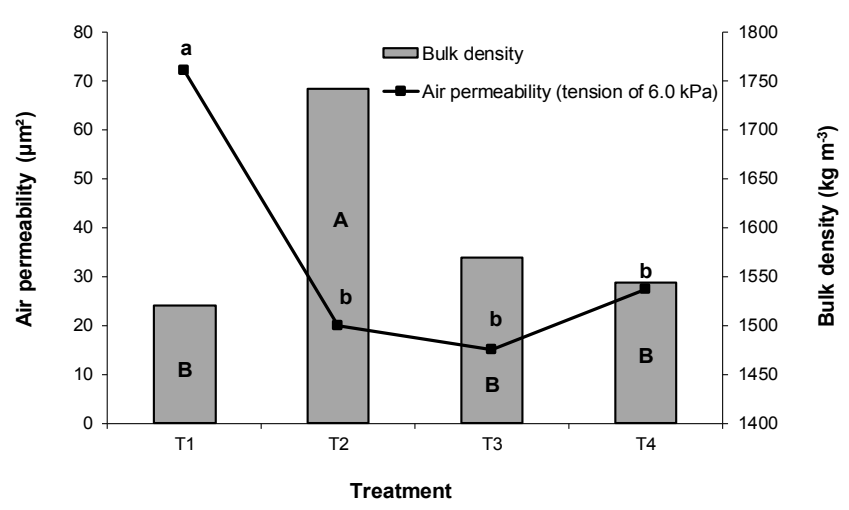

Figure 5. Bulk density and air permeability in the natural state of the Latossolo in the layers of 0-0.1 $\mathrm{m}(\mathrm{T} 1)$ and 0.1-0.2 m (T2) and of the Planossolo in the layers of 0-0.1 m (T3) and 0.1-0.2 m (T4). Means were compared by Tukey test at $5 \%$ probability level

In the Planossolo, animal trampling had major impact on bulk density, especially in the surface layer. Increased clay contents in the soil profile combined with heavy machinery traffic on the soil led to reductions in soil air permeability values (Chen, Weil, \& Hill, 2014). Kuncoro, Koga, Satta, and Muto (2014) also noted that the increase in compaction led to a significant reduction in soil air permeability, probably attributed to a reduced volume of macropores.

Soil compaction, indicated by bulk density, caused drastic reduction in soil air permeability, demonstrating the importance of adopting good agricultural practices, although it is important to use other attributes such as total porosity, macroporosity and microporosity to help interpret the results. Soil air permeability depends basically on two factors, moisture content and bulk density, and both influence the geometry and continuity of the soil pore system (Silva et al., 2009).

The air permeability of the compacted Latossolo (normal Proctor test) in the 0-0.1 m layer was higher (35.25\%) than that in the 0.1-0.2 m layer, since the compacted soil density in the latter was slightly higher than in the former (Figure 6). Highest air permeability was observed in the Latossolo in the $0-0.1 \mathrm{~m}$ layer, statistically differing from the surface layer of the Planossolo, which is due to the higher sand content of this layer (64.3\%).

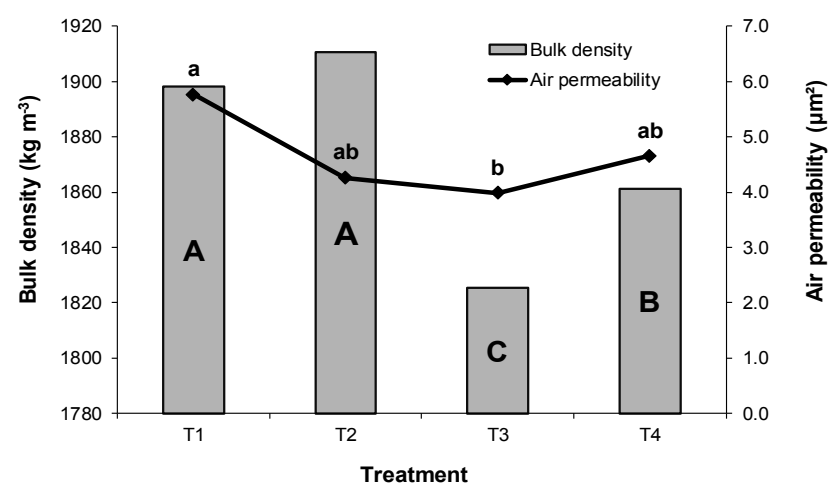

Figure 6. Bulk density and air permeability under maximum compaction of the Latossolo in the layers of 0-0.1 $\mathrm{m}$ (T1) and 0.1-0.2 m (T2) and of the Planossolo in the layers of 0-0.1 m (T3) and 0.1-0.2 m (T4). Means were compared by Duncan test at $5 \%$ probability level

Such inverse relationship between bulk density and air permeability is also found in soils that have $\mathrm{B}_{\mathrm{t}}$ horizons with cohesive character, which are less functional than those having $B_{t}$ horizons without cohesive character, with lower air permeability, pore length and connectivity. Regardless of how well the pores are oriented, the highest percentage of blocked pores, i.e., those which do not contribute to air flow, occurs in horizons with cohesive character (Menezes et al., 2018).

The relative soil air permeability $\left(\mathrm{K}_{\text {airr }}\right)$ of the Latossolo in the layers of 0-0.1 m and 0.1-0.2 $\mathrm{m}$ was equal to 0.1032 and 0.3547 , respectively. In the Planossolo, the values were 0.4115 and 0.1923 in the layers of $0-0.1 \mathrm{~m}$ 
and 0.1-0.2 m, respectively (Figure 7). Thus, a relative soil air permeability of 0.3 can be considered as critical, and above this value the soil has physical restrictions, with great possibility of effects on the yields of agricultural crops.
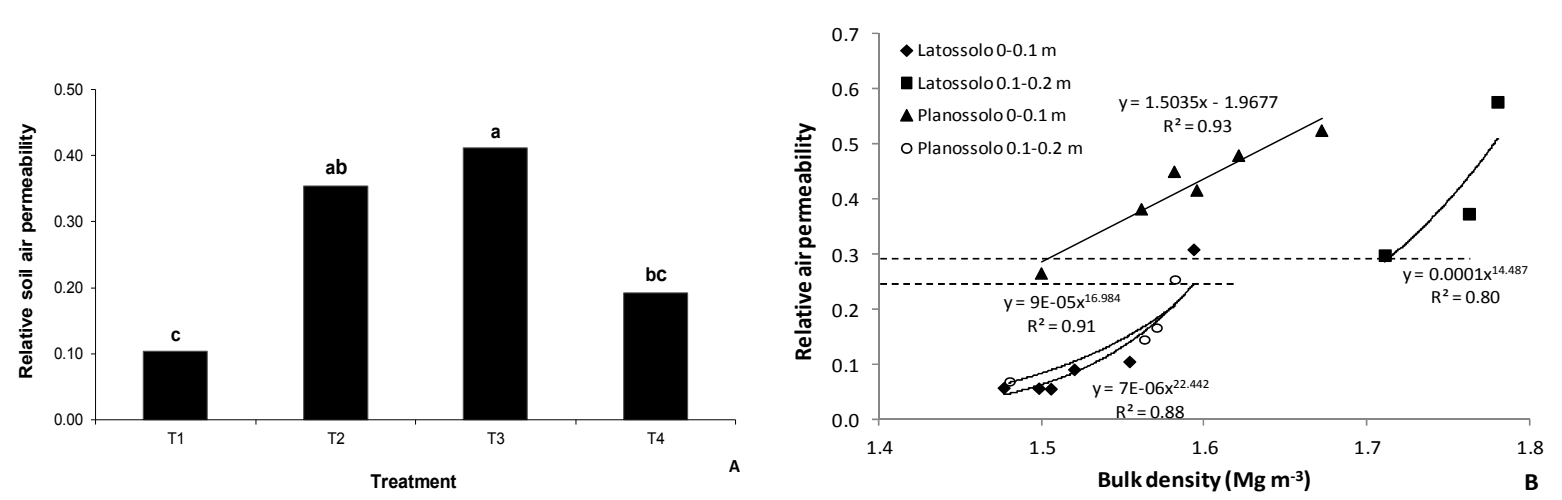

Figure 7. Relative air permeability of the Latossolo and Planossolo in the layers of 0-0.1 $\mathrm{m}$ (T1 and T3, respectively) and 0.1-0.2 $\mathrm{m}$ (T2 and T4, respectively), with means compared by Tukey test at 5\% probability level (A) and regression between relative soil air permeability and bulk density (B)

\section{Conclusions}

The Latossolo in the 0-0.1 m layer and the Planossolo in the 0.1-0.2 m layer showed values of relative soil air permeability close to 0.10 and 0.20 , respectively, which indicate good physical quality.

The Latossolo in the 0.1-0.2 m layer and the Planossolo in the 0-0.1 m layer showed high values of relative soil air permeability, indicating that the value of 0.3 is critical for root development in more sensitive crops and may compromise the yields of agricultural crops.

The types of soil and layers are separated according to their intrinsic characteristics and to the different managements of the areas, which is explained by the differences between their physical attributes.

\section{References}

Ahuja, L. R., Naney, J. W., Green, R. E., \& Nielsen, D. R. (1984). Macroporosity to Characterize Spatial Variability of Hydraulic Conductivity and Effects of Land Management1. Soil Science Society of America Journal, 48(4), 699. https://doi.org/10.2136/sssaj1984.036159950048000

Blackwell, P. S., Ringrose-Voase, A. J., Jayawardane, N. S., Olsson, K. A., Mckenzie, D. C., \& Mason, W. K. (1990). The use of air-filled porosity and intrinsic permeability to air to characterize structure of macropore space and saturated hydraulic conductivity of clay soils. Journal of Soil Science, 41(2), 215-228. https://doi.org/10.1111/j.1365-2389.1990.tb00058.x

Brian, R., Venables, B., Bates, D. M., Hornik, K., Gebhardt, A., \& Firth, D. (2018). Mass: Support Functions and Datasets for Venables and Ripley's MASS (Version 7.3-50). Retrieved from http://www.stats.ox.ac.uk/ pub/MASS4

Brown, V., Barbosa, F.T., Bertoll, I., Mafral, A. L., \& Muzekal, L. M. (2018). Efeitos no solo e nas culturas após vinte anos de cultivo convencional e semeadura direta. Revista Brasileira de Ciências Agrárias, 13, 1-7. https://doi.org/10.5039/agraria.v13i1a5501

Camargo, O. A., Moniz, A. C., Jorge, J. A., \& Valadares, J. M. A. S. (1986). Métodos de análise química, mineralógica e física de solos do Instituto Agronômico de Campinas (Boletim Técnico, No. 106). Campinas, SP: Instituto Agronômico.

Cavalieri, K. M. V., da Silva, A. P., Tormena, C. A., Leão, T. P., Dexter, A. R., \& Håkansson, I. (2009). Long-term effects of no-tillage on dynamic soil physical properties in a Rhodic Ferrasol in Paraná, Brazil. Soil and Tillage Research, 103(1), 158-164. https://doi.org/10.1016/j.still.2008.10.014

Chen, G., Weil, R. R., \& Hill, R. L. (2014). Effects of compaction and cover crops on soil least limiting water range and air permeability. Soil and Tillage Research, 136, 61-69. https://doi.org/10.1016/j.still. 2013.09.004 
Chief, K., Ferré, T. P. A., \& Nijssen, B. (2006). Field Testing of a Soil Corer Air Permeameter (SCAP) in Desert Soils. Vadose Zone Journal, 5(4), 1257. https://doi.org/10.2136/vzj2006.0063

Collis-George, N. (1953). Relationship between air and water permeabilities in porous media. Soil Science, 76, 239-250. https://doi.org/10.1097/00010694-195310000-00001

Dexter, A. R. (2004). Soil physical quality - Part I. Theory, effects of soil texture, density, and organic matter, and effects on root growth. Geoderma, 120(3-4), 201-214. https://doi.org/10.1016/j.geoderma.2003.09.004

Farhan, S., Holsen, T. M., \& Budiman, J. (2001). Interaction of Soil Air Permeability and Soil Vapor Extraction. Journal of Environmental Engineering, 127(1), 32-37. https://doi.org/10.1061/(asce)0733-9372(2001) $127: 1(32)$

Ferreira, E. B., Cavalcanti, P. P., \& Nogueira, D. A. (2018). Pacote Experimental Designs (Portuguese) (Version 1.2.0). Retrieved from https://cran.r-project.org/package=ExpDes.pt

Gee, G. W, \& Or, D. (2002). Particle-size analysis. In J. H. Dane, \& G. C. Topp (Eds.), Methods of soil analysis: Physical methods (pp. 255-289). Madison: American Society of Agronomy.

Groenevelt, P. H., Kay, B. D., \& Grant, C. D. (1984). Physical assessment of a soil with respect to rooting potential. Geoderma, 34(2), 101-114. https://doi.org/10.1016/0016-7061(84)90016-8

Guedes Filho, O., Silva, A. P., Giarola, N. F. B., \& Tormena, C. A. (2015). Permeabilidade ao ar da cama de semeadura do solo em sistema semeadura direta. Revista Brasileira de Ciência do Solo, 39, 841-851. https://doi.org/10.1590/01000683rbcs20140169

Guimarães, R. M. L., Tormena, C. A., Blainski, E., \& Fidalski, J. (2013). Intervalo hídrico ótimo para avaliação da degradação física do solo. Revista Brasileira de Ciência do Solo, 37, 1512-1521.

Iversen, B. V., Moldrup, P., Schjønning, P., \& Loll, P. (2001). Air and water permeability in differently textured soils at two measurement scales. Soil Science, 166(10), 643-659. https://doi.org/10.1097/00010694200110000-00001

Jesus, M. C., Brito, A. S., Silva, M. O., Teixeira, S. S., \& Carvalho, W. D. (2017). Permeabilidade ao ar e porosidade de solos na região semiárida. Revista Engenharia na Agricultura, 25, 230-239. https://doi.org/ 10.13083/reveng.v25i3.739

Kirkham, D. (1947). Field Method for Determination of Air Permeability of Soil in its Undisturbed State1. Soil Science Society of America Journal, 11(C), 93. https://doi.org/10.2136/sssaj1947.036159950011000

Klein, A.V., Madalosso, T., \& Baseggio, M. (2013). Ensaio de Proctor normal-análise metodológica e planilha para cálculo da densidade do solo máxima e o teor de água ótimo. Revista de Ciências Agroveterinárias, 12, 199-203.

Klein, V. A., Baseggio, M., \& Madalosso, T. (2009). Indicadores da qualidade física de um Latossolo Vermelho distrófico típico sob plantio direto escarificado. Ciência Rural, 39(9), 2475-2481. https://doi.org/10.1590/ s0103-84782009005000225

Kuncoro, P. H., Koga, K., Satta, N., \& Muto, Y. (2014). A study on the effect of compaction on transport properties of soil gas and water I: Relative gas diffusivity, air permeability, and saturated hydraulic conductivity. Soil and Tillage Research, 143, 172-179. https://doi.org/10.1016/j.still.2014.02.006

Libardi, P. L. (2012). Dinâmica da água no solo. São Paulo: EDUSP.

Loll, P., Moldrup, P., Schjønning, P., \& Riley, H. (1999). Predicting saturated hydraulic conductivity from air permeability: Application in stochastic water infiltration modeling. Water Resources Research, 35(8), 2387-2400. https://doi.org/10.1029/1999wr900137

Loss, A., Pereira, M. G., Giácomo, S. G., Perin, A., \& Anjos, L. H. C. dos. (2011). Agregação, carbono e nitrogênio em agregados do solo sob plantio direto com integração lavoura-pecuária. Pesquisa Agropecuária Brasileira, 46(10), 1269-1276. https://doi.org/10.1590/s0100-204x2011001000022

Luciano, R. V., Albuquerque, J. A., Costa, A., Batistella, B., \& Armling, M. T. (2012). Atributos físicos relacionados à compactação de solos sob vegetação nativa em região de altitude no sul do Brasil. Revista Brasileira de Ciência do Solo, 36, 1733-44. http://doi.org/10.1590/S0100-06832012000600007

Klein, V. A., \& Marcolin, C. D. (2011). Determinação da densidade relativa do solo por uma função de pedotransferência para a densidade do solo máxima. Acta Scientiarum. Agronomy, 33(2). https://doi.org/ 10.4025/actasciagron.v33i2.6120 
Martínez, I., Chervet, A., Weisskopf, P., Sturny, W. G., Rek, J., \& Keller, T. (2016). Two decades of no-till in the Oberacker long-term field experiment: Part II. Soil porosity and gas transport parameters. Soil and Tillage Research, 163, 130-140. https://doi.org/10.1016/j.still.2016.05.020

Menezes, A. S., Alencar, T. L., Assis Júnior, R. N., Toma, R. S., Romero, R. E., Costa, M. C. G., ... Mota, J. C. A. (2018). Functionality of the porous network of Bt horizons of soils with and without cohesive character. Geoderma, 313, 290-297. https://doi.org/10.1016/j.geoderma.2017.11.005

Moreira, F. R., Dechen, S. C. F., Silva, A. P., Figueireda, G. C., Maria, I. C., \& Pessoni, P. T. (2014). Intervalo hídrico ótimo em um Latossolo Vermelho cultivado em sistema semeadura direta por 25 anos. Revista Brasileira de Ciência do Solo, 38, 118-127. https://doi.org/10.1590/S0100-06832014000100011

Ohland, T., Lana, M. do C., Frandoloso, J. F., Rampim, L., Bergmann, J. R., \& Cabreira, D. T. (2014). Influência da densidade do solo no desenvolvimento inicial do pinhão-manso cultivado em Latossolo Vermelho eutroférrico. Revista Ceres, 61(5), 622-630. https://doi.org/10.1590/0034-737x201461050004

Oliveira, L. B., Ribeiro, M. R., Ferraz, F. B., Ferreira, M. G. V. X., Mermut, A. R. (2004). Mineralogia, micromorfologia e gênese de solos planossólicos do sertão do Araripe, estado de Pernambuco. Revista Brasileira de Ciência do Solo, 28, 665-678. https://doi.org/10.1590/S0100-06832004000400009

$\mathrm{R}$ development core team. (2010). R: A Language and environment for statistical computing (Version R-3.5.0). Retrieved from https://www.r-project.org

Raducu, D., \& Voicu, P. (2015). The air permeability as important parameter of soil environment. Journal of Biotechnology, 208, S59. https://doi.org/10.1016/j.jbiotec.2015.06.175

Rahmati, M., \& Neyshaboury, M. R. (2016). Soil Air Permeability Modeling and Its Use for Predicting Unsaturated Soil Hydraulic Conductivity. Soil Science Society of America Journal, 80(6), 1507. https://doi.org/10.2136/sssaj2015.12.0430

Reynolds, W. D., Drury, C. F., Tan, C. S., Fox, C. A., \& Yang, X. M. (2009). Use of indicators and pore volume-function characteristics to quantify soil physical quality. Geoderma, 152(3-4), 252-263. https://doi.org/10.1016/j.geoderma.2009.06.009

Rodrigues, S., Silva, A. P., Giarola, N. F. B., \& Rosa, J. A. (2011). Soil air permeability in a Rhodic Hapludox under different tillage systems. Revista Brasileira de Ciência do Solo, 35, 105-114. http://doi.org/10.1590/ S0100-06832011000100010

Santos, J. L. D., Santos, L. G., Souza, V. N., Bahia, B. L., \& Rodrigues, T. F. (2013). Caracterização física e química de um planossolo localizado no semiárido baiano. Enciclopedia Biosfera, 9, 625-634.

Schjønning, P., \& Koppelgaard, M. (2017). The Forchheimer Approach for Soil Air Permeability Measurement. Soil Science Society of America Journal, 81(5), 1045. https://doi.org/10.2136/sssaj2017.02.0056

Shi, J., Wu, X., Ai, Y., \& Zhang, Z. (2018). Laboratory test investigations on soil water characteristic curve and air permeability of municipal solid waste. Waste Management \& Research, 36(5), 463-470. https://doi.org/ $10.1177 / 0734242 \times 18766223$

Silva, F. R., Albuquerque, J. A., \& Costa, A. (2014). Crescimento inicial da cultura da soja em Latossolo bruno com diferentes graus de compactação. Revista Brasileira de Ciência do Solo, 38, 1731-1739. http://doi.org/ $10.1590 / \mathrm{S} 0100-06832014000600008$

Silva, A. P., Leão, T. P., Tormena, C. A., \& Gonçalves, A. C. A. (2009). Determinação da permeabilidade ao ar em amostras indeformadas de solo pelo método da pressão decrescente. Revista Brasileira de Ciência do Solo, 33(6), 1535-1545. https://doi.org/10.1590/S0100-06832009000600003

Silveira, L. R. da, Brito, A. dos S., Mota, J. C. A., Moraes, S. O., \& Libardi, P. L. (2011). Sistema de aquisição de dados para equipamento de medida da permeabilidade intrínseca do solo ao ar. Revista Brasileira de Ciência Do Solo, 35(2), 429-436. https://doi.org/10.1590/s0100-06832011000200012

Stefanoski, D. C., Santos, G. G., Marchão, R. L., Petter, F. A., \& Pacheco, L. P. (2013). Uso e manejo do solo e seus impactos sobre a qualidade física. Revista Brasileira de Engenharia Agrícola e Ambiental, 17(12), 1301-1309. https://doi.org/10.1590/s1415-43662013001200008

Stone, L. F., Guimarães, C. M., Moreira, J. A. A. (2002). Compactação do solo na cultura do feijoeiro. Compactação do solo na cultura do feijoeiro. I: efeitos nas propriedades físico-hídricas do solo. Revista Brasileira de Engenharia Agrícola e Ambiental, 6, 207-212. https://doi.org/10.1590/S1415-43662002000 200004 
Tang, A. M., Cui, Y.-J., Richard, G., \& Défossez, P. (2011). A study on the air permeability as affected by compression of three French soils. Geoderma, 162(1-2), 171-181. https://doi.org/10.1016/j.geoderma. 2011.01 .019

Tuli, A., Hopmans, J. W., Rolston, D. E., \& Moldrup, P. (2005). Comparison of Air and Water Permeability between Disturbed and Undisturbed Soils. Soil Science Society of America Journal, 69(5), 1361. https://doi.org/10.2136/sssaj2004.0332

Venables, W. N., 7 Ripley, B. D. (2002). Modern Applied Statistics with S (4th ed.). New York, NY: Springer. https://doi.org/10.1007/978-0-387-21706-2

Viana, E. T., Batista, M. A., Tormena, C. A., Costa, A. C. S. da, \& Inoue, T. T. (2011). Atributos físicos e carbono orgânico em latossolo vermelho sob diferentes sistemas de uso e manejo. Revista Brasileira de Ciência Do Solo, 35(6), 2105-2114. https://doi.org/10.1590/s0100-06832011000600025

\section{Copyrights}

Copyright for this article is retained by the author(s), with first publication rights granted to the journal.

This is an open-access article distributed under the terms and conditions of the Creative Commons Attribution license (http://creativecommons.org/licenses/by/4.0/). 